\title{
BW A773U
}

National Cancer Institute

\section{Source}

National Cancer Institute. BW A773U. NCI Thesaurus. Code C1339.

A three substituted fluoranthene derivative of the 2-(arylmethylamino)-1,3-propanediol family that intercalates with DNA, causing inhibition of DNA synthesis. $(\mathrm{NCl})$ 